\title{
Using E-Module Based on Historical Thinking Skill as a Distance Learning Solution
}

\author{
Ruli Seftiana Aziza ${ }^{1}{ }^{*}$ Nana Supriatna ${ }^{2}$ \\ ${ }^{1,2}$ History Education Study Program, School of Postgraduate Universitas Pendidikan Indonesia, West \\ Java 40154, Indonesia \\ *Email: rseftianaaziza@gmail.com
}

\begin{abstract}
In this pandemic covid 19 era. The learning process has been changing a lot, which was previously carried out by face to face method, now it must be transferred to online learning. There are several challenges of learning process if we using technologies, starting from the availability of computer devices, cellphones, the signal, the smoothness of communication, and others are about the problems of learning materials, how can the teacher arranged materials as simple as posible, so the learning process become easier to understand, and how can the students and the teacher manage their time the best as they can. Students are required to be able to learn independently even outside the real time of the class. explore and build their own knowledge with various available learning resources. Therefore, the teacher inevitably has to think about various strategies and ways that they can do, so that learning objectives can still be achieved even using distance learning process. Teachers must be creative arraging the learning materials, especially in History subject, so the students have some interest in digging further more about the History material. One of them is by using electronic-based modules that are compiled using historical thinking skill indicators. The materials and questions are creatively arranged so that creative students are also in solving problems in learning. The goal is to make history learning more meaningful and contextual with students' daily lives rather than just the fact of the date and time of an event.
\end{abstract}

Keywords: E-Module, Historical Thinking Skill, Distance Learning Process, Covid-19. 


\section{INTRODUCTION}

In the era of the Covid-19 pandemic, the learning process underwent a change which was previously carried out face-to-face and now has to be transferred to online or distance learning. One of the options offered by the government through Permendikbud no. 4 of 2002 concerning the implementation of education policies in emergencies. Likewise on May 18, 2020, the Ministry of Education and Culture launched circular number 15 of 2020 concerning guidelines for organizing learning from home in the emergency period of the spread of the corona virus or Covid-19. As one of the strategic steps for what is happening, there have been a number of innovations at all levels of education from elementary to tertiary education to facilitate SFH (School From Home) practice by utilizing various available digital platforms such as Zoom, Google Classroom, Edomodo Digital. Learning, I Spring Learning, Quizizz Online Learning and so on. The use of these platforms is to provide a meaningful learning experience for students without feeling burdened [1].

The Covid-19 pandemic era also requires students to study independently even outside the study class in order to explore knowledge and not to miss the subject matter, so that apart from the factor of teachers who have to develop new learning strategies, students are also required to be independent to seek, explore and build. own knowledge with various available learning resources.In the aspect of professional competence, there needs to be an increase in the ability of teachers to absorb quickly, critically, and deeply the abundant information available in cyberspace so that it can produce useful knowledge for learning. In addition, teacher competence also needs to be improved in terms of the ability to make packages and learning modules that are flexible, attractive, and easily accessible and digestible by students.

The Ministry of Education and Culture through Hamid Muhammad said that the Ministry of Education and Culture prepared modules for distance learning with the aim that students can study independently at home, especially for students whose areas are not exposed to the internet because both modules and e-modules can be obtained in hardcopy, while e-modules can be compressed via e-mail and other platforms, then downloaded and can be accessed offline.

Important teaching materials are used in learning for both teachers and students to achieve learning objectives based on expected competencies. With teacher teaching materials that were initially positioned as the only source of information in the classroom, then they are directed to become facilitators who help and direct students in learning. While students who were originally positioned as passive learners, using teaching materials can trigger students to be more active because they learn the material in the teaching materials before class starts so that when learning, students are ready with sufficient information and knowledge. In the end there is time effectiveness where the teacher does not need to explain the material at length and there is learning efficiency, students become easier to understand learning materials and time allocation can be used for discussion of certain materials that are not yet understood by students.

\section{METHOD}

The method used is the literature review method based on Ramdhani et al [2]. Several stages in this method, namely selecting a topic, searching for articles related to the topic, identifying literature, then compiling review articles systematically. The topic raised in this article is about the use of historical thinking skills based e modules as a distance learning solution.

\section{RESULT AND DISCUSSION}

\subsection{Purpose of Using Modules for \\ Distance Learning}

E-modules are all printed teaching materials that have been integrated with information technology (ICT) so that they can be accessed through the website or combined on a CD-ROM.

According to Triyono [3] the benefits of using $\mathrm{E}$ module in learning are beneficial for teachers and students. For teachers, of course, in designing modules, they 
must develop their abilities independently through various available sources, for example all kinds of books, articles, journals, the internet and so on so that teachers can be creative in managing learning, and using modules will reduce miscommunication in the delivery of subject matter. As for students, the use of $E$ module can reduce student dependence on the presence of teachers in the classroom, students can learn independently by following the instructions in the E module, students can measure their ability to master the material directly through the exercises provided and learning becomes more flexible.

The teaching objectives of the module are as follows: 1) To open opportunities for students to learn at their own pace. It is assumed that students will not achieve the same results at the same time and are not willing to learn the same things at the same time; 2) Provide opportunities for students to learn according to their respective learning styles, therefore they use different techniques to solve certain problems based on their respective background knowledge and habits. Good teaching modules provide a variety of instructional, such as reading textbooks, library books, magazines, slides, listening to audio-tapes; 3) Clarify and facilitate the presentation of the message so that it is not too verbal; 4) Overcoming the limitations of time, space, and students' senses; 5) Educational objectives can be achieved effectively and efficiently; 6) Modules are prepared based on the principle of "mastery learning", which is a concept that emphasizes that students must optimally or master the subject matter presented through modules [4].

According to Santyasa [5] the benefits obtained from learning with the application of modules are: 1) increasing student motivation, because each time they do a lesson that is clearly defined and in accordance with their abilities; 2) after the evaluation, the teacher and students know correctly which modules the students have succeeded in and which parts of the modules they have not succeeded 3) students achieve results according to their abilities; 4) lesson materials are distributed more evenly in one semester; 5) education is more efficient, because the learning materials are arranged according to academic levels.

The preparation of the E-module is intended to make it easier for students to learn independently and to become a stimulus in improving students' historical thinking skills because through the use of modules students are able to understand the subject matter, harmonize it with daily life, solve problems contained in module worksheets, practice questions, draw conclusions and so on which are arranged based on the structure or framework of the module so that it makes it easier for students to understand the subject matter and the flow of the module. As for teachers, the use of modules can make it easier for teachers to deliver subject matter and become a medium for teachers to get feedback from students.

The characteristics of the module in general are 1) Self instructional (independent instruction), that is, the module can enable students to teach themselves using the available modules. To fulfill the self-instructional character, in Creative Writing teaching materials there are clearly formulated goals, both final and intermediate goals. In designing e modules, instructions and instructions for using the module are clearly conveyed which are packaged in specific units and activities to make it easier for students to use the module; 2) Self contained (adequate material), which is all subject matter from one competency unit or sub-competency contained in the e module as a whole. So, students can read and study the material per sub without significant obstacles; 3) Stand alone (stand alone), that is, the modules used do not depend on the media or other learning resources. use of the E module can be used alone without depending on the use of other learning resources; 4) Adaptive, that is, the module has high adaptive power to the development of science and technology. The module is designed in electronic form, not a printed module, so that students can easily access it and even open it via cellphone which can be read and repeated anytime and anywhere; 5) User friendly (easy to use), that is, every instruction and exposure to information that appears is helpful and friendly to the wearer, including the ease with which the user responds and accesses as desired.

\subsection{Using E-Module as a Distance Learning Solution}

Based on research conducted by Rezki Kurniawan et al. [6], it shows that the application of e-modules combined with the $\mathrm{PjBL}$ learning model is considered effective in improving the quality of learning in digital simulation subjects in vocational schools, especially during a pandemic such as what happened today.

Sunita [7] in her research stated that one of the media suitable for distance learning is e-module, which is a printed module component that is processed in such a way that 
it is transformed into an electronic form. The use of e-modules makes learning interesting for students because it can be accessed anytime and anywhere. The advantage for the teacher is that the teacher is easier to provide instruction in learning. E-module is a means of learning that includes materials, methods, and also provides learning evaluation that is designed practically so that it attracts student interest in learning.

Janti Sri Rahayu [8] said in her article that modules are an alternative to distance learning during the Covid 19 Pandemic. By using modules, students are required to understand and work on modules coherently according to the instructions in the module. The teacher can also find out the extent to which parents can assist students in learning and the extent to which students can understand the material that has been given through the summary of the module.

Another study conducted by Kinzie Feliciano Pinontoa et al. [9] showed that the results of the calculation of reasoning ability obtained an average of 85.55 for the experimental class and 74.34 for the control class and the calculation of entrepreneurial intentions showed that the average difference between initial and final IB was 8.54 . This shows that there is a positive effect of implementing flipped classrooms with e-module support in online learning statistics on students' reasoning abilities and entrepreneurial intentions.

Research conducted by Siti Aisyah [10] on the development of a distance learning module. The research produced modules with good categories, the quality of presentation of the modules was in a good category consisting of presentation layouts, language and systematics, materials and interactive learning designs so that they could be used for the learning process.

Research from Revita Yuni and Roni Afriadi [11] shows that the module developed is valid (feasible) to be used as teaching material based on the assessment of material experts and media experts. The module is one of the offline learning solutions (outside the network) during the Covid 19 pandemic. Modules that are conditional can be used by students independently.

Finally, the research conducted by Suwasono [12] shows that the development of Analog Electronics e-module for distance education meets the valid criteria so that it is feasible to be used for the learning process.

Based on the results of the review obtained, it can be concluded that the application of e-modules in learning as a distance learning solution is considered effective to be applied in the history learning process, especially during the pandemic as is currently happening.

\subsection{Historical Thinking Skill in Historical Learning}

Historical thinking skills are the ability for students to distinguish past, present, and future, see and evaluate evidence, compare and analyze historical stories, illustrations, and records from the past, interpret historical records, and construct a historical stories based on his understanding [13].

According to Becker in Wineburg [14], historical thinking is called on to see human motive in the texts we read; called on to mine truth from the quicksand of innuendo, half truth and false hood that seeks to engulf is each day; called on to brave the fact that certainty, at least in understanding the social world, remains elusive and beyond our gasp. Historical thinking is seeing every motive that causes an event to occur, distinguishing a fact, half true and lying and not swallowing it raw, daring to reveal definite facts, at least understanding the social environment.

The Braedly Commissions on History School and the National Standard for Historyreveal in detail about the ability to think historically, historical thinking involves the explorations and analysis of historical documents, places, artifacts, and other records of the past. This requeres the children thoughtfully listen to and read well written historical narrative that reveal conditions, changes, and consequences, and that explain why happened as they did. Analysis of the events disribe and the explanations offered, in tandem and comparasion with historical artifac, record, and the human figures involved, bring's a child ability to think historical thinking fill circle.

So it can be seen that historical thinking is studying history sequentially and completely, as well as understanding the most important of the concepts of space and time. Historical thinking can invite students to re-track existing historical data, then collect it, study it, analyze, translate and draw conclusions and be open to various opinions supported by evidence. Historical thinking indirectly invites students to take the role of a historian.

According to Lawrence [15] the ability to think historically consists of nine indicators, namely: 1) Historical causation (understanding of patterns of causality (cause 
and effect); 2) Patterns of continuity and change over time (understanding patterns of continuity and change from time to time; 3 ) Periodization (understanding the timekeeping or grouping of time based on age; 4) Comparison (comparing); 5) Contextualization (connecting the knowledge that students have in their application with everyday life; 6) Historical argumentation (compiling arguments or opinions); 7) Appropriate use of relevant historical evidence (using evidence that is appropriate and reliable; 8) Interpretation (translating or analyzing existing historical evidence; 9) Synthesis (produce a conclusion that exists based on existing data until it becomes a historical fact).

\subsection{Steps for Preparing E-Module}

To compile a module, the teacher must pay attention to the basic competencies that will be achieved by students by referring to the lesson plans that have been made, because the material in the module is compiled from the competencies to be achieved, then design evaluation tools in such a way starting from tests, student worksheets, or initial competencies. students and last but not least is to use language that is simple and easy to understand. In general, the steps in compiling an e-module are as follows;

- Determine the title of the material to be discussed, determine the KD subject matter

- Refer to the syllabus

- Compiling teaching materials by collecting sources such as books, articles, videos, historical videos and so on

- Arrange questions about questions

- Prepare RPP

- Arrange modules according to module components: title, glossary, concept map, general instructions; Basic Competencies, Subjects, Achievement Indicators, material, summary, exercises, practical activity sheets, answer keys, evaluation, references.

- Integrating it into the application, applications that can be used to compile an e-module include flipbook maker, Caliber, Sigil, Mobipocket creator, ePUBeemaker, eXelearning, live worksheet.

In a module, the most important thing is how the subject matter can be presented concisely in simple and communicative language. As well as the questions or questions in it must be arranged referring to middle or high-level thinking skills so that history learning becomes more effective. In the distance learning process or independently, compiling HOTS and MOTS questions is important in order to explore students' knowledge and understanding of history learning so that history learning becomes more meaningful and contextual with the knowledge students already have. The skills that students must have in learning History are the ability to think historically (histrorical thinking skills) involves the ability to understand text, analyze, compare, test, evaluate, make decisions, conclude, contextualize it with existing knowledge and reality. Mthrough historical thinking will lead students to take a thinking approach in accordance with scientific characteristics. In this case, students are invited to be involved in thinking about why the event happened, the pattern of causality from an event and its relation to the present context. The basic concept in historical thinking is an understanding of the three elements of history itself, namely humans, space and time, this is the entrance to understanding history so that history learning becomes more meaningful. Anderson \& Krathwohl (2001) [16] classify the dimensions of thought processes as follows.

\section{Thinking Process Dimensions}

\begin{tabular}{|c|c|c|}
\hline \multirow{3}{*}{$\begin{array}{l}\text { HOTS } \\
\text { Higher Order } \\
\text { Thinking Skills }\end{array}$} & Create & $\begin{array}{l}\text { - Create your own ideas / ideas. } \\
\text { - Verbs: construct, design, create, develop, write, combine, } \\
\text { formulate. }\end{array}$ \\
\hline & Evaluate & $\begin{array}{l}\text { - Make decisions about the quality of information. } \\
\text { - Verbs: evaluate, judge, argue, decide, choose, support, } \\
\text { suspect, predict. }\end{array}$ \\
\hline & Analyze & $\begin{array}{l}\text { - } \quad \text { Specifies aspects / elements. } \\
\text { - } \quad \text { Verbs: parse, compare, examine, criticize, test. }\end{array}$ \\
\hline $\begin{array}{l}\text { MOTS } \\
\text { Middle }\end{array}$ & Apply & $\begin{array}{l}\text { - Use information on a different domain. } \\
\text { - Verbs: use, demonstrate, illustrate, operate. }\end{array}$ \\
\hline
\end{tabular}




\begin{tabular}{|c|c|c|}
\hline Thinking Skills & & \\
\hline \multirow{2}{*}{$\begin{array}{l}\text { LOTS } \\
\text { Lower Order } \\
\text { Thinking Skills }\end{array}$} & Understand & $\begin{array}{l}\text { - Explain the idea / concept. } \\
\text { - } \quad \text { Verbs: explain, classify, accept, report. }\end{array}$ \\
\hline & Remember & $\begin{array}{l}\text { - } \quad \text { Recall facts, concepts and procedures. } \\
\text { - } \quad \text { Verbs: remember, register, repeat, mimic. }\end{array}$ \\
\hline
\end{tabular}

Puspendik (2015) classifies them into 3 cognitive levels, namely level 1 (knowledge and understanding), level 2 (application), and level 3 (reasoning).

\subsection{E-Module Based on Historical Thinking Skill}

\begin{tabular}{|c|c|c|}
\hline No. & Historical Thinking Skill & Example of the question \\
\hline 1 & Historical Causation & $\begin{array}{l}\text { The text of the Jakarta charter that has been compiled by } \\
\text { the committee of nine should be the text of the } \\
\text { proclamation of independence, but ultimately not used at } \\
\text { the proclamation of August } 17,1945 \text {, explain why it can } \\
\text { happen? }\end{array}$ \\
\hline 2 & $\begin{array}{l}\text { Patterns of continuity and } \\
\text { change over time }\end{array}$ & $\begin{array}{l}\text { After Indonesia's independence, Muhammad Hatta issued } \\
\text { information no X dated November 3,1945 that caused } \\
\text { many political parties (multiparty). currently in Indonesia } \\
\text { has quite a lot of parties. Is this the embodiment of } \\
\text { democracy or it can cause instability in the government, } \\
\text { what do you think, include by example! }\end{array}$ \\
\hline 3 & Periodization & $\begin{array}{l}\text { Draw a timeline from the events of the rengasdenglok to the } \\
\text { proclamation! }\end{array}$ \\
\hline 4 & Comparison & $\begin{array}{l}\text { One day in 1960, Muhammad Hatta spoke with Mr. } \\
\text { Wangsa, "the history of the world hints that the dictator } \\
\text { who depends on the authority of people will not be long his } \\
\text { age", in 1956, Hatta resigned from the vice president's chair } \\
\text { so that there is a jargon "Soekarno Hatta Dwitunggal the } \\
\text { Date", why it happened so, what causes the two often } \\
\text { different views, then what lessons can be taken from the } \\
\text { two proclamators? }\end{array}$ \\
\hline \multirow[t]{2}{*}{5} & Contextualization & What can you do in order to fill Indonesia's independence? \\
\hline & Argumentation & $\begin{array}{l}\text { Do you agree with the view that nationalism has faded } \\
\text { among the younger generation? }\end{array}$ \\
\hline 7 & $\begin{array}{l}\text { Apropriate use of relevant } \\
\text { historical evidence }\end{array}$ & $\begin{array}{l}\text { In his } 1950 \text { speech, President Sukarno called for the } \\
\text { Indonesian nation to be colonized for } 350 \text { years, many } \\
\text { textbooks stated that but other opinions say that Indonesia } \\
\text { was not colonized during that time. How's your analysis, } \\
\text { explain it! }\end{array}$ \\
\hline 8 & Interpretation & $\begin{array}{l}\text { In the text of the first paraphrasing proclamation it is said } \\
\text { that the Indonesian nation declares Indonesia's } \\
\text { independence, while in the second paragraph there is the } \\
\text { phrase "transfer of power" which means that there has not } \\
\text { been a complete transfer of power (tearing down the first } \\
\text { paragraph declaring independence), and when is the } \\
\text { transfer of power? the transfer of power from whom to } \\
\text { whom while at that time Indonesia is still regional and has } \\
\text { not shaped a country?, how do you analyze, explain it! }\end{array}$ \\
\hline
\end{tabular}




\begin{tabular}{|l|l|}
\hline 9 & Synthesis \\
& \\
\hline
\end{tabular}

Imagine by you if Bung Karno did not proclaim Indonesia's independence on August 17, 1945, what are the possibilities that could happen?

\section{CONCLUSION}

The distance learning process makes the teacher have to think of various ways so that the learning process continues and learning objectives can be achieved as they should. There are many strategies and ways that teachers can do, one of which is to use e-modules during the learning process, especially history learning. Based on the results of reviews of several articles, it can be seen that the use of e-modules is very appropriate to use during the learning process because of the characteristics of the modules that allow students to continue to take lessons even though they are not during class hours. The use of e-modules is an alternative for teachers in presenting lessons during the distance learning process.

E-modules based on historical thinking skills are arranged based on questions that can explore students 'historical thinking skills so that history learning is not just memorizing historical facts but so that students' understanding of history becomes more meaningful and long lasting.

\section{REFERENCES}

[1] Darmawan \& Ruhimat. 2021. Pembelajaran Jarak Jauh: Pendekatan \& Implementasi VCDLN, Teknologi Televisis dan E Learning. Bandung: Remaja Rosdakarya.

[2] A. Ramdhani, M. A. Ramdhani, and A. S. Amin. 2014. "Writing a Literature Review Research Paper: A step by step approach". Int. J. Basic Appl. Sci, vol. 3, no. 1, pp. 47-56.

[3] Triyono, Slamet. 2021. Dinamika Penyusunan E Modul. Indramayu: Penerbit Adab, pp. 7-8

[4] Suryosubroto. 2002. Proses Belajar Mengajar Di Sekolah. Jakarta: Rineka Cipta, pp. 9.

[5] Santyasa, I Wayan. 2009. Metode Penelitian Pengembangan dan Teori Pengembangan Modul. Jogjakarta: Universitas Gadjah Mada, pp. 11. E-Modul Berbasis Project Based Learning Selama Pembelajaran Jarak Jauh". Jurnal Vokasi Informatika, vol. 1, no. 1, pp. 1-4.

[7] Sunita, Nita. 2020. Media Pembelajaran Modul Elektronik (E-Modul) Sebagai Sarana Pembelajaran Jarak Jauh. UNJ.

[8] Rahayu, Janti Sri. 2020. Modul, Alternatif Pembelajaran Jarak Jauh di Masa Pandemik Covid-19.https://radarsemarang.jawapo s.com/rubrik/untukmu-guruku/2020/10/ 07/modul-alternatif-pembelajaran-jarak -jauh-di-masa-pandemik-covid-19/ (diakses tanggal 12 April 2021).

[9] Pinontoan, Kinzie Feliciano, Mario Walean dan Andrew Vandy Lengkong. 2021. "Pembelajaran Daring Menggunakan E-Modul Pada Flipped Classroom Statistika Untuk Meningkatkan Kemampuan Bernalar dan Intensi Berwirausaha". Jurnal Inovasi Teknologi Pembelajaran, vol. 8, no. 1, pp. 1-10.

[10] Aisyah, Siti, Mani Festati Broto dan Anto Hidayat. Pengembangan Model Bahan Ajar Jarak Jauh Pada Mata Kuliag Sistem Kepartaian dan Pemilu (IPEM), pp. 90-97.

[11] Yuni, Revita dan Roni Afriadi. 2020. "Pengembangan Modul Pembelajaran Kondisional Untuk Belajar Dari Rumah ( BDR)". Jurnal Handayam UNIMED, vol.11, no.2, pp. 144-152.

Suwasono. 2013. "Pengembangan E-Modul Online Elektronik Analog Pada Pendidikan Jarak Jauh". Jurnal Teknologi dan Kejuruan, vol. 36, no.1, pp. 51-62.

[13] Isjoni. (2007). Pembelajaran Sejarah Pada Satuan Pendidikan. Bandung: Alpabeta, pp. 82.

[14] Wineburg, S. (2001). Historical Thinking and Other Unnatural Acts: Charting the Future of Teaching the Past (Critical Perspectives on The
Rezki, Indra Kurniawan, Joni Karnando dan Elfi Tasrif. 2021. "Efektivitas 
Past). Philadelphia, PA: Temple University Press, pp.127.

[15] Charap Lawrence G. 2015. Assesing Historical Thinking in the Redesigned Advanced Placement United States History Course and Exam. Routledge : New York, pp.163.

[16] Anderson, L.W., danKrathwohl, D.R.(2001). A Taxonomy for Learning, Teaching, and Assesing; A revision of Bloom's Taxonomy of Education Objectives. New York:

Addison Wesley Lonman Inc. 